\title{
PENGARUH KARAKTERISTIK SOSIODEMOGRAFI TERHADAP SELF EFFICACY PEREMPUAN KELUARGA MISKIN DALAM MELAKSANAKAN USAHA EKONOMI PRODUKTIF DI SURAKARTA
}

\author{
Suminah $^{1)}$, Sunarru Samsi Hariadi ${ }^{2)}$, Sri Widodo ${ }^{3)}$, Sri Peni Wastutiningsih ${ }^{4)}$ \\ 1) Mahasiswa Pascasarjana Universitas Gadjah Mada \\ 2) Promotor Disertasi \\ 3,4) Ko-Promotor Disertasi
}

\begin{abstract}
This study aimed to analyze the influence of sociodemographic characteristics to the self-efficacy on women of poor households (WPH) in implementing economically productive activities. The study was conducted at Surakarta, using a survey approach. Samples were taken by multistage random sampling technique. Quantitative data were analyzed using multiple regression models. The results showed that the factors sociodemographic characteristics: age, formal education, and the number of family dependents significant affect on self-efficacy of WPH in conducting productive business at significance level $\alpha=0.10$, whereas the non-formal education and long effort had no significant affect. Goodness of fit test results of multiple linear regression model showed that the sociodemographic characteristics collectively have the affect of 28.6 percent.
\end{abstract}

Keywords: sociodemographic characteristics, self-efficacy of women, economically productive activities

\begin{abstract}
Abstrak: Studi ini bertujuan untuk menganalisis pengaruh karakteristik sosiodemografi terhadap self efficacy perempuan keluarga miskin dalam melaksanakan usaha ekonomi produktif. Studi ini dilakukan di Surakarta, dengan menggunakan pendekatan survai. Sampel penelitian di ambil dari sebagian perempuan keluarga miskin yang menjalankan usaha ekonomi produktif dengan menggunakan teknik multistage random sampling. Analisis data dilakukan secara kuantitatif dengan model regresi ganda. Hasil penelitian menunjukkan bahwa faktor karakteristik sosiodemografi: umur, pendidikan formal, dan jumlah tanggungan keluarga berpengaruh signifikan terhadap self efficacy perempuan rumah tangga miskin dalam melaksanakan usaha ekonomi produktif pada taraf signifikasi $\alpha=0,10$, sedangkan pendidikan non formal dan lama usaha tidak berpengaruh signifikan. Hasil uji goodness of fit model regresi linear berganda menunjukkan bahwa karakteristik sosiodemografi secara bersama memiliki pengaruh sebesar 28,6 persen.
\end{abstract}

Kata kunci: karakteristik sosiodemografi, self-efficacy perempuan, usaha ekonomi produktif

\section{PENDAHULUAN}

Kemiskinan merupakan salah satu masalah serius dalam proses pembangunan nasional di Indonesia. Berdasarkan data BPS (2012), jumlah penduduk miskin di Indonesia pada September 2011 mencapai angka 29,89 juta orang (12,36 persen), turun 0,13 juta orang $(0,13$ persen $)$ dibandingkan dengan penduduk miskin pada Maret 2011 yang sebesar 30,02 juta orang (12,49 persen). Di Jawa Tengah, jumlah penduduk miskin pada September 2012 mencapai angka 5.255,99 juta orang (16,14 persen), jauh lebih besar dibandingkan dengan rata-rata jumlah penduduk miskin di Indonesia yang hanya sebesar 12,36 persen (BPS, 2012). Tercatat dalam BPS (2011) tahun 2010 persentase penduduk miskin di Surakarta 
sebesar 13,98 persen, jauh lebih besar dibandingkan dengan kabupaten yang berada di Solo Raya, seperti kabupaten Boyolali 13,79 persen; kabupaten Klaten 10,35 persen; kabupaten Sukoharjo 10,65 persen; Kabupaten Wonogiri 11,68 persen; dan Kabupaten Karanganyar 12,96 persen.

Himbauan Presiden RI pada

Konferensi Nasional Pembangunan Manusia tahun 2006 agar semua pihak memberikan perhatian dan dukungan terhadap pencapaian sasaran dan target-target MDGs, termasuk mengatasi tingkat kemiskinan yang belum dapat diatasi yang dijabarkan dalam Instruksi Presiden Nomor 3 tahun 2010 mengamanatkan pembangunan yang berkeadilan adalah pembangunan yang pro rakyat yang prioritas utamanya penanggulangan kemiskinan berbasis keluarga. Berkaitan dengan penanggulangan kemiskinan, program pemberdayaan perempuan merupakan salah satu program yang diharapkan dapat berkontribusi untuk menanggulangi kemiskinan. Pemberdayaan perempuan dalam pembangunan ekonomi merupakan salah satu strategi pembangunan yang strategis dan tepat dalam upaya pengentasan kemiskinan.

Berbagai skeme program pemberdayaan untuk pengentasan kemiskinan, telah dilakukan oleh berbagai pihak, sebagai suatu gerakan untuk menggerakkan keterlibatan perempuan dalam menanggulangi kemiskinan dan perluasan kesempatan kerja, guna peningkatan kualitas hidup, kemandirian dan kesejahteraan masyarakat. Pemberdayaan peningkatan ekonomi perempuan rumah tangga miskin menjadi salah satu fokus utamanya, melalui berbagai upaya pemberdayaan ekonomi produktif. Namun, kenyataannya upaya pemberdayaan tersebut belum mampu mengatasi persoalan kemiskinan yang ada di Indonesia terutama untuk perempuan rumah tangga miskin. Diduga belum berhasilnya pemberdayaan perempuan rumah tangga miskin tersebut lebih banyak ditentukan oleh faktor psikologis perempuan itu sendiri, selain faktor non psikologis yang mempengaruhinya.

Perempuan yang bekerja meskipun telah memiliki kemampuan alami dengan baik yang telah dilengkapi dengan pelatihan yang relevan dan sukses disertai dengan alat bantu yang tepat, namun faktor psikologi seperti motivasi dan self efficacy juga menentukan tingkat keberhasilan individu dalam melaksanakan pekerjaannya (Rini, 2005). Self efficacy seseorang menentukan seberapa besar usaha dan motivasi seseorang dalam bekerja dan menyelesaikan pekerjaannya (Bandura, 1997). Lebih lanjut dijelaskan bahwa tanpa adanya keyakinan bahwa tindakan mereka dapat menghasilkan sesuatu yang diinginkan atau mencegah hal-hal yang tidak diinginkan, mereka tidak memiliki modal yang cukup untuk bertindak. Perilaku individu merupakan hasil dari proses belajar yang dilalui sepanjang hidupnya dan dipengaruhi oleh banyak faktor. Levin (Utami, 2006) membuat persamaan dasar perilaku manusia adalah $\mathrm{B}=\mathrm{f}(\mathrm{P}, \mathrm{S})$, merumuskan bahwa perilaku (B) adalah fungsi dari faktor-faktor atau karakteristik yang bersifat individual $(\mathrm{P})$ dengan situasi dan kondisi lingkungan dimana individu itu berada (S).

Self efficacy adalah keyakinan dalam diri seseorang bahwa mampu menghadapi situasi tertentu. Self efficacy tersebut dapat mempengaruhi persepsi, motivasi dan tindakannya dalam berbagai cara, dan mampu mempengaruhi seberapa banyak upaya yang digunakan dan seberapa lama seseorang dapat bertahan dalam mengatasi kehidupan yang sulit (Stajkovic dan Luthan, 1998). Self efficacy adalah keyakinan seseorang untuk dapat berprestasi dengan baik dalam suatu situasi (Gibson et al. 1997). Dengan demikian, self efficacy merupakan sumber motivasi yang penting bagi seseorang untuk sukses dalam pekerjaan, sehingga perlu dikaji karakteristik sosiodemografi apa saja yang mempengaruhi tingkat self efficacy seseorang. Perbedaan karakteristik tersebut sedikit banyak akan menyebabkan terjadinya perbedaan perilaku individu, baik dalam bekerja maupun dalam mengelola usaha untuk memenuhi kebutuhan rumah tangganya. Untuk itu dalam penelitian ini berusaha untuk menjawab tujuan penelitian tentang faktor sosiodemografi apa saja yang mempengaruhi tingkat self efficacy perempuan RTM dalam usaha ekonomi produktif di Surakarta.

\section{METODE PENELITIAN}

Studi ini, menggunakan metode kuantitatif dengan pendekatan survai. Lokasi penelitian di Surakarta. Populasi dalam penelitian ini adalah 
semua perempuan rumah tangga miskin yang melaksanakan usaha ekonomi produktif dibidang pangan dan atau kerajinan. Teknik pengambilan sampel dilakukan dengan multistage random sampling, sebagai berikut: (1) menetapkan lokasi kecamatan yang ditentukan secara random yaitu dari lima kecamatan diambil sebanyak tiga kecamatan; (2) menetapkan lokasi kelurahan dari masingmasing kecamatan terpilih; (3) dari masingmasing kelurahan terpilih kemudian dibuat daftar nama (sample frame) yang kemudian diambil responden perempuan rumah tangga miskin yang melaksanakan usaha ekonomi produktif, secara proposional random sampling.

\section{Uji Validitas dan Reliabilitas}

Uji validitas item instrumen menggunakan formula koefisien korelasi product moment Pearson, dengan kriteria penilaian uji validitas apabila $r$ hitung $>r$ tabel (pada taraf signifikasi $\alpha=0,05)$ maka dapat dikatakan item kuesioner adalah valid. Sedangkan reliabilitas diukur menggunakan Alpha Cronbach. Nilai Alpha Cronbach pada penelitian ini menggunakan standar 0,60 dengan asumsi bahwa daftar pertanyaan/pernyataan yang diuji akan reliabel apabila nilai Alpha Cronbach $\geq 0,60$ (Ghozali, 2011).

Hasil uji reliabilitas instrumen dalam studi ini menunjukkan bahwa nilai reliabilitas seluruh variabel adalah memiliki nilai alpha cronbach di atas 0,60 , sehingga dapat ditarik kesimpulan bahwa ukuran setiap variabel penelitian ini adalah reliabel. Sedangkan hasil uji validitas item instrumen menunjukkan semua item valid karena nilai correlated itemtotal correlation-nya (CITC) lebih besar dari $\mathrm{r}$ tabel pada taraf signifikansi $\alpha=0,05$ yaitu 0,25 .

\section{Uji Asumsi Klasik Pada Regresi}

Data sebelum dianalisis dilakukan uji asumsi klasik terlebih dulu, yang meliputi uji normalitas data, uji multikolinearitas, uji heteroskedastisitas sebagai berikut:

\section{1) Uji normalitas}

Salah satu cara yang dapat digunakan untuk uji normalitas data adalah dengan melihat nilai rasio skewness dan rasio kurtosis. Data dikatakan terdistribusi normal jika berada pada rentang -2,58 dan $+2,58$ (Santoso, 2002). Berdasarkan uji normalitas data dengan melihat nilai rasio skewness dan rasio kurtosis, diperoleh hasil seperti ditunjukkkan Tabel 1.

Dari hasil uji normalitas pada Tabel 1, dapat diketahui bahwa nilai yang dihasilkan berada pada rentang $-2,58$ dan $+2,58$ sehingga data tersebut dapat diartikan terdistribusi normal.

\section{2) Uji multikolinearitas}

Pengujian ada tidaknya gejala multikolinearitas pada studi ini yaitu dengan pengukuran terhadap Varian Inflation Factor (VIF) pada hasil regresi. Untuk menunjukan adanya multikolinearitas adalah tolerance $<0,10$ atau sama dengan nilai VIF $>10$ (Santoso, 2002). Berdasarkan hasil uji multikolinearitas diperoleh hasil bahwa karakteristik sosiodemografi diduga mempengaruhi self efficacy perempuan rumah tangga miskin dalam melaksanakan usaha ekonomi produktif, terbebas dari gejala multikolinearitas atau dengan kata lain antara variabel bebas tidak saling tumpang tindih mempengaruhi satu sama lain. Secara ringkas nilai tolerance dan VIF dapat dilihat pada Tabel 2.

Tabel 1. Uji Normalitas Data Menggunakan Teknik Rasio Skewness dan Rasio

\begin{tabular}{cccccc}
\hline \multirow{2}{*}{ Variabel } & Skewness & Kurtosis & & & \\
\cline { 2 - 5 } & Statistic & Std.Error & Rasio & Statistic & Std.Error \\
\hline X1 & $-0,014$ & 0,309 & 0.661 & $-0,046$ & 0.608 \\
X2 & 0,114 & 0,309 & 1.274 & $-0,377$ & 0.608 \\
X3 & 1,226 & 0,309 & 1.202 & 1,017 & 0.608 \\
X4 & 0,789 & 0,309 & 1.123 & $-0,560$ & 0.608 \\
X5 & $-0,330$ & 0,309 & 1.030 & 0,448 & 0.608 \\
Y1 & 0,781 & 0,309 & 0.847 & 0,172 & 0.608 \\
\hline
\end{tabular}

Sumber: Analisa Data Primer, 2013 
Suminah, Sunarru Samsi H., Sri Widodo, Sri Peni W.: Pengaruh Karakteristik. ...

Tabel 2. Hasil Uji Multikolinearitas

\begin{tabular}{lcc}
\hline \multirow{2}{*}{ Variabel } & \multicolumn{2}{c}{ Collinearity Statistics } \\
\cline { 2 - 3 } & Tolerance & VIF \\
\hline Umur & 0,847 & 1,181 \\
Pendidikan formal & 0,756 & 1,323 \\
Pendidikan non formal & 0,764 & 1,31 \\
Lama Usaha & 0,821 & 1,219 \\
Jumlah tanggungan keluarga & 0,998 & 1,002 \\
\hline
\end{tabular}

Sumber: Analisa Data Primer, 2013

\section{3) Uji heteroskedastisitas}

Untuk mendeteksi ada tidaknya gejala heteroskedastis dalam studi ini adalah dengan melihat grafik plot antara nilai prediksi dengan residualnya, adapun dasar untuk menganalisisnya sebagai berikut:

a) Jika ada pola tertentu (bergelombang, melebar, menyempit) maka mengindikasikan terjadinya heteroskedastisitas.

b) Jika tidak ada pola serta titik menyebar diatas dan dibawah angka nol pada sumbu Y, maka tidak terjadi heteroskedastisitas atau terjadi homokedastisitas.

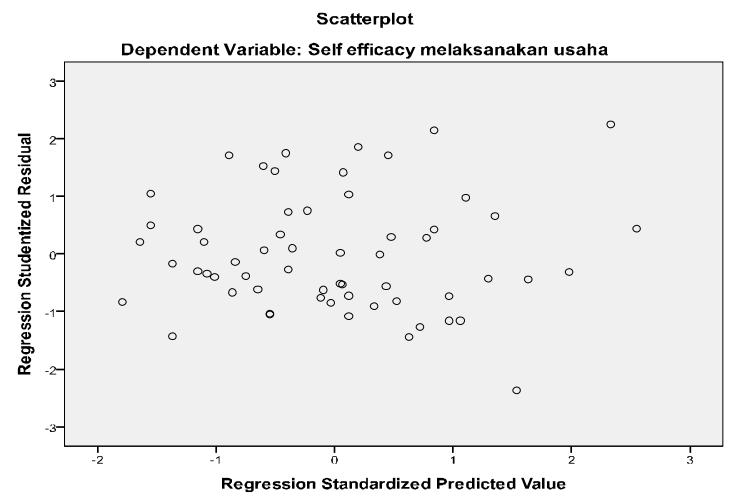

Gambar 1. Hasil Uji Heteroskedastis

Berdasarkan uji heteroskedastis dengan teknik Scatter-Plot ditunjukkan pada gambar 1, terlihat titik-titik data menyebar tanpa ada pola bentuk yang teratur sehingga dapat dikatakan model regresi tidak terjadi gejala heteroskedastis.

\section{HASIL DAN PEMBAHASAN}

\section{Uji Model Regresi Linear Berganda}

Untuk menguji pengaruh karakteristik sosiodemografi terhadap self efficacy perempuan rumah tangga miskin dalam usaha ekonomi produktif digunakan model analisis regresi berganda dengan melakukan beberapa prosedur sebagai berikut:

1) Uji koefisien determinasi $\left(R^{2}\right)$ atau $R$ Square yaitu untuk mengetahui apakah variabel dependen dapat dijelaskan oleh variabel independen secara bersama-sama. Nilai R Square berkisar antara 0 hingga 1 . Jika R Square mendekati angka 0 maka semakin lemah variabel-variabel bebas dalam menjelaskan variabel terikat. Begitu juga sebaliknya, jika nilai $R$ Square mendekati angka 1 maka semakin kuat variabel-variabel independen dalam menjelaskan variabel dependen.

2) Uji $F$ yaitu untuk mengetahui pengaruh semua variabel bebas secara bersama-sama terhadap variabel terikat pada uji ANOVA. Apabila nilai $\mathrm{F}$ hitung lebih kecil dari signifikansi $0,05 \quad(\alpha=0,05)$, berarti variabel-variabel independen bersamasama berpengaruh terhadap variabel dependen.

3) Uji t yaitu untuk melihat adanya pengaruh setiap variabel independen terhadap variabel dependen dilakukan dengan cara melihat nilai t hitung pada hasil analisis regresi linear berganda.

\section{Distribusi karateristik sosiodemografi perempuan rumah tangga miskin dalam usaha ekonomi produktif}

Karakteristik sosiodemografi yang akan dibahas dalam studi ini antara lain umur, pendidikan formal, pendidikan non formal, lama usaha dan jumlah tanggungan keluarga dapat dilihat pada Tabel 3. 
Suminah, Sunarru Samsi H., Sri Widodo, Sri Peni W.: Pengaruh Karakteristik. ...

Tabel 3. Distribusi Karakteristik Sosiodemografi Perempuan Keluarga Miskin

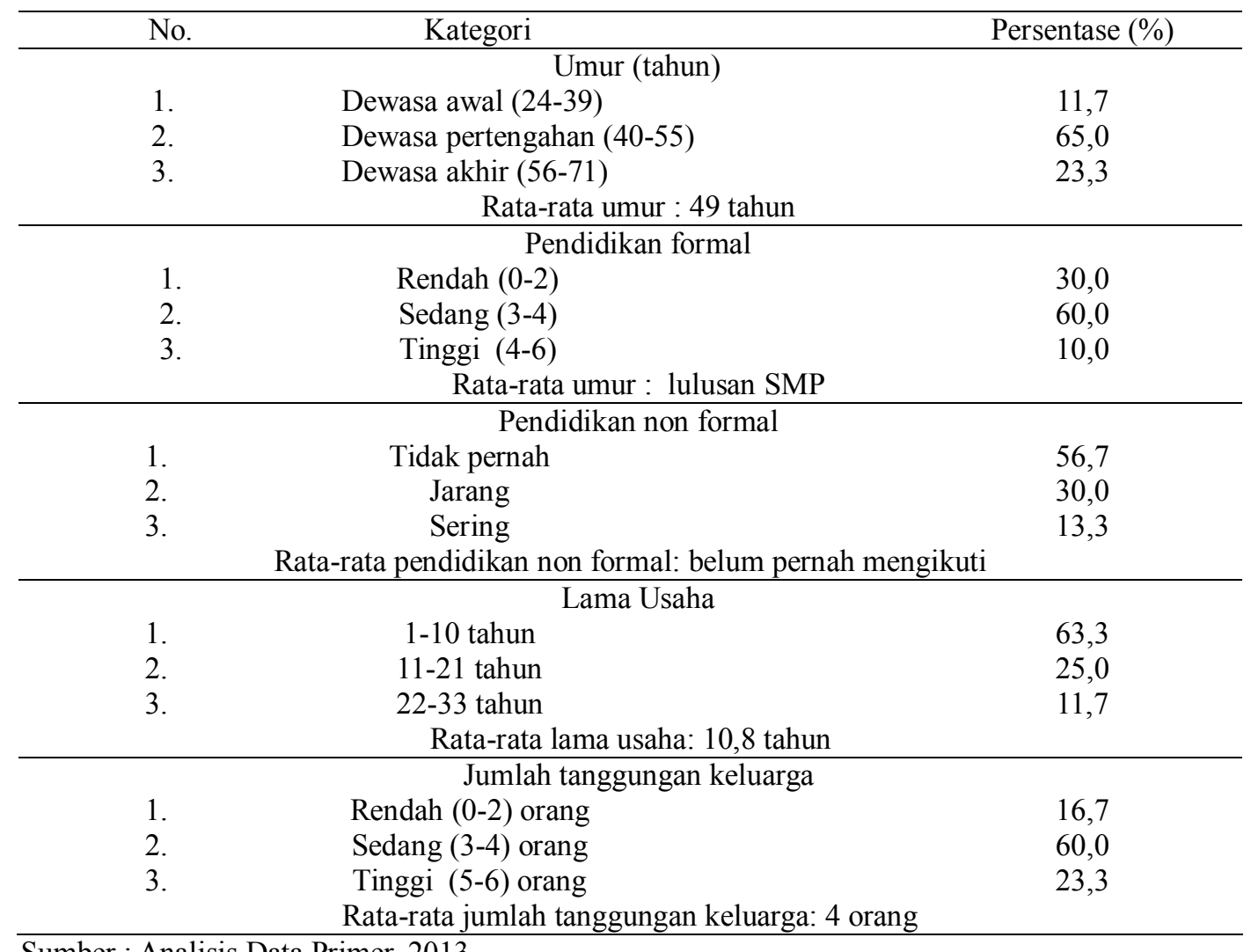

Sumber : Analisis Data Primer, 2013

Umur perempuan rumah tangga miskin di Surakarta berkisar antara 24 sampai dengan 71 tahun. Pada Tabel 3 memperlihatkan bahwa berdasarkan rata-rata umur perempuan keluarga miskin, dapat dikatakan mempunyai fisik yang masih tergolong kuat dan termasuk dalam kategori produktif karena umur berkaitan dengan kemampuan fisik seseorang. Tidak adanya perempuan rumah tangga miskin yang berumur di bawah 24 tahun menimbulkan kekawatiran tentang keberlajutan kegiatan usaha ekonomi produktif yang berada di Surakarta.

Tingkat pendidikan formal yang dimiliki oleh perempuan rumah tangga miskin sangat beragam yaitu mulai dari tidak sekolah hingga diploma. Distribusi tingkat pendidikan perempuan rumah tangga miskin pada Tabel 3, terlihat bahwa tingkat pendidikan sebagian besar adalah lulus SMP yaitu sebesar 36 persen. Dalam hal ini terlihat bahwa tingkat pendidikan dapat dikategorikan sedang. Dari total seluruh perempuan rumah tangga miskin hanya 10 persen orang yang pernah mengenyam pendidikan sampai perguruan tinggi, yaitu lulusan diploma. Tingkat pendidikan perempuan rumah tangga miskin tersebut sedikit banyak dipengaruhi oleh tingkat pendapatan keluarga yang relatif kecil, sehingga tidak melanjutkan ke jenjang pendidikan yang lebih tinggi.

Pada Tabel 3 menunjukkan bahwa perempuan rumah tangga miskin yang belum pernah mengikuti pendidikan non sebanyak 56,7 persen. Hal ini memperlihatkan bahwa sebagian besar perempuan rumah tangga miskin belum pernah mengikuti pelatihan atau penyuluhan yang berkaitan dengan usaha ekonomi produktif yang dijalankan. Kondisi ini sangat memprehatinkan karena kenyataannya hanya 13,3 persen yang pernah mengikuti pendidikan non formal baik dalam bentuk pelatihan maupun penyuluhan yang berkaitan dengan bidang usahanya. Hal ini berarti masih banyak perempuan rumah tangga miskin yang melaksanakan usaha ekonomi produktif tetapi belum tersentuh oleh program pemberdayaan, meskipun sudah banyak skem pemberdayaan yang diluncurkan oleh berbagai pihak. 
Lama usaha dalam studi ini adalah lamanya perempuan rumah tangga miskin dalam melaksanakan usaha ekonomi produktif yang dinyatakan dalam tahun. Deskripsi tentang lama usaha dalam melaksanakan usaha ekonomi produktif ini diperlukan karena diduga semakin lama perempuan rumah tangga miskin menjalankan usaha, maka akan semakin tinggi tingkat self efficacy-nya, sehingga semakin berhasil usahanya. Pada Tabel 3 menunjukkan bahwa mayoritas perempuan rumah tangga miskin (65,3 persen) sudah berusaha selama kurang lebih 10 tahun, dan bahkan ada 11,7 persen perempuan yang sudah berusaha lebih dari 20 tahun.

Jumlah tanggungan keluarga yang dimiliki oleh perempuan rumah tangga miskin dalam satu keluarga sangat beragam mulai dari yang tidak memiliki tanggungan keluarga sama sekali hingga ada yang memiliki 6 orang tanggungan keluarga. Sebagian besar jumlah tanggungan keluarga yang dimiliki oleh perempuan rumah tangga miskin adalah 3-4 orang yaitu sebanyak 60 persen. Rumah tangga yang tidak memiliki tanggungan keluarga hanya 1 orang, dan selebihnya memiliki jumlah tanggungan keluarga 5-6 orang sebesar 23,3 persen.

\section{Pengaruh Karakteristik Sosiodemografi Terhadap Self Efficacy Perempu-an Keluarga Miskin}

Hasil analisis regresi linear berganda menunjukkan bahwa pengaruh masing-masing variabel independen (umur, pendidikan formal, pendidikan non formal, lama usaha, dan jumlah tanggungan keluarga) terhadap variabel dependen (self efficacy perempuan keluarga miskin dalam melaksanakan usaha ekonomi produktif) dapat dilihat pada Tabel 4. Dari nilai kooefisien regresi dan hasil uji t, atau dengan melihat nilai signifikansi (sig)-nya pada Tabel 4 dapat diketahui bahwa variabel karakteristik sosiodemografi perempuan rumah tangga miskin, ada yang berpengaruh signifikan dan ada yang tidak berpengaruh signifikan pada tingkat signifikansi $=0,10$ terhadap variabel self efficacy perempuan rumah tangga miskin dalam melaksanakan usaha ekonomi produktif. Hal ini berarti tidak semua karakteristik sosiodemografi yang dikonsepsikan memiliki pengaruh signifikan terhadap self efficacy perempuan keluarga miskin dalam melaksanakan usaha ekonomi produktif. Hasil analisis regresi dapat dilihat pada Tabel 4.

Dari hasil analisis regresi seperti tersebut dalam Tabel 4 dapat disusun model persamaan regresinya sebagai berikut:

$\mathrm{Y}_{1}=1,747-0,342 \mathrm{X}_{1}+0,295 \mathrm{X}_{2}+0,485 \mathrm{X}_{5}$

\section{Keterangan:}

$\mathrm{Y}_{1}=$ self efficacy (keyakinan diri) mampu melaksanakan usaha

$\mathrm{X}_{1}=$ umur perempuan rumah tangga miskin

$\mathrm{X}_{2}=$ pendidikan formal

$\mathrm{X}_{3}=$ pendidikan non formal

$\mathrm{X}_{4}=$ lama usaha

$\mathrm{X}_{5}=$ jumlah tanggungan keluarga

Tabel 4. Hasil Analisis Regresi Karakteristik Sosiodemografi Terhadap Self Efficacy Perempuan Keluarga Miskin

\begin{tabular}{llcc}
\hline Variabel & $\begin{array}{l}\text { Koefisien } \\
\text { Regresi }\end{array}$ & t-hitung & signifikasi \\
\hline Konstanta & $\left.1,747^{* * *}\right)$ & 3,534 & 0,001 \\
Umur & $-0,342 *)$ & $-1,567$ & 0,091 \\
Pendidikan formal & $\left.0,295^{*}\right)$ & 1,973 & 0,054 \\
Pendidikan non formal & $0,100 \mathrm{NS})$ & 0,898 & 0,373 \\
Lama usaha & $-0,072 \mathrm{NS})$ & $-1,192$ & 0,238 \\
Jumlah tanggungan keluarga & $\left.0,485^{*}\right)$ & 1,617 & 0,083 \\
F hitung & $\left.2,783^{* * *}\right)$ & & 0,026 \\
Adjusted R Square & 0,286 & & \\
\hline
\end{tabular}

Sumber : Analisis Data Primer, 2013

Keterangan: $* * *)$ signifikan pada $\alpha=0,01 ; * *$ ) signifikan pada $\alpha=0,05 ; *$ ) signifikan pada $\alpha=0,10$; NS) non signifikan pada $\alpha=0,10$ 
Berdasarkan hasil model persamaan regresi yang diperoleh diketahui bahwa untuk variabel pendidikan non formal $\left(\mathrm{X}_{3}\right)$ dan lama usaha $\left(\mathrm{X}_{4}\right)$ tidak layak masuk dalam model regresi untuk metode enter, karena kedua variabel tersebut tidak memberikan pengaruh terhadap self efficacy perempuan rumah tangga miskin dalam melaksanakan usaha ekonomi produktif, sehingga semakin banyak kegiatan pelatihan atau penyuluhan yang diikuti maupun semakin lama waktu dalam melaksanakan usaha tidak memberikan dampak terhadap self efficacy dalam melaksanakan usaha ekonomi produktif.

Pengaruh masing-masing variabel independen (umur, pendidikan formal, pendidikan non formal, lama usaha, dan jumlah tanggungan keluarga) terhadap variabel dependen (self efficacy perempuan rumah tangga miskin dalam melaksanakan usaha ekonomi produktif) dapat dilihat dari nilai kooefisien regresinya dan hasil uji t, atau dengan melihat nilai signifikansi (sig). Dari Tabel 4 dapat diketahui bahwa variabel karakteristik sosiodemografi: umur, pendidikan formal, dan jumlah tanggungan keluarga berpengaruh signifikan pada taraf signifikansi $=0,10$. Sedangkan variabel pendidikan non formal dan lama usaha tidak berpengaruh signifikan pada tingkat signifikansi $=0,10$ terhadap variabel self efficacy perempuan rumah tangga miskin dalam melaksanakan usaha ekonomi produktif.

\section{1) $\operatorname{Umur}\left(X_{1}\right)$}

Pada Tabel 4 menunjukkkan bahwa variabel umur berpengaruh signifikan terhadap self efficacy perempuan rumah tangga miskin dalam melaksanakan usaha ekonomi produktif dengan koefisien regresi sebesar $-0,342$, dengan nilai thitung sebesar -1,567 lebih besar dari nilai ttabel pada taraf signifikansi sebesar $=0,10$, yaitu sebesar 1,290. Dari hasil analisis menunjukkan bahwa umur berpengaruh negatif terhadap self efficacy perempuan rumah tangga miskin dalam melaksanakan usaha ekonomi produktif. Kondisi ini dapat dijelaskan bahwa semakin bertambah umur maka self efficacynya dalam melaksanakan usaha ekonomi produktif semakin rendah, atau semakin muda umur perempuan rumah tangga miskin, maka self efficacy-nya semakin tinggi.
Pada umur tertentu kemampuan fisik manusia akan semakin meningkat, sehingga produktivitasnya naik, demikian pula sebaliknya semakin tua umur, maka keadaan fisiknya akan semakin menurun dan produktivitasnya pun akan menurun. Hal ini sesuai dengan pernyataan Tjitropranoto (1994) bahwa umur seseorang diduga kuat mempengaruhi kemampuannya, baik kemampuan fisik maupun kemampuan berfikir. Kondisi ini juga relevan dengan kajian Dahama dan Bhatnagar (1980), yang menyatakan bahwa kapasitas bekerja seseorang umumnya berkembang cepat sampai umur sekitar 50 tahun, kemudian berangsur-angsur berkurang kapasitasnya. Hasil pengamatan di lapang memperlihatkan bahwa perempuan rumah tangga miskin yang dalam kategori dewasa akhir atau tua tidak memiliki keyakinan diri yang tinggi untuk dapat mengakses pinjaman modal usaha, melakukan proses produksi, memasarkan produksinya, dan menjalin kemitraan dengan pihak lain. Kondisi ini dapat dijelaskan bahwa untuk memperoleh pinjaman modal memang ada beberapa persyaratan yang harus dipenuhi berkaitan dengan administrasi. Dalam melakukan proses produksi karena umurnya sudah tua maka kondisi fisiknya juga semakin menurun, demikian juga dalam memasarkan produk dan menjalin kemitraan dengan pihak lain.

\section{2) Pendidikan Formal $\left(X_{2}\right)$}

Pendidikan formal perempuan rumah tangga miskin berpengaruh signifikan pada taraf signifikansi $=0,10$ terhadap self efficacy perempuan keluarga miskin dalam melaksanakan usaha ekonomi produktif. Dengan demikian dapat diartikan bahwa tinggi rendahnya tingkat pendidikan formal perempuan keluarga miskin dapat mengakibatkan tinggi rendahnya self efficacy perempuan rumah tangga miskin dalam melaksanakan usaha ekonomi produktif. Hasil analisis pada Tabel 4 dapat dilihat pengaruhnya positif dengan koefisien regresi sebesar 0,295, dan nilai t-hitung sebesar 1,973 lebih besar dari nilai t-tabel dengan taraf signifikansi $=0,10$ yaitu sebesar 1,290. Hal ini berarti semakin tinggi tingkat pendidikan formal maka semakin tinggi self efficacy-nya. Hal ini dapat dimaknai bahwa tinggi rendahnya pendidikan formal perempuan keluarga miskin mempengaruhi 
tingkat self efficacy-nya dalam melaksanakan usaha ekonomi produktif di Surakarta. Dalam studi ini, tingkat pendidikan formal yang lebih tinggi menyebabkan meningkatnya self efficacy perempuan keluarga miskin dalam melaksanakan usaha ekonomi produktif. Berkaitan dengan tingkat pendidikan formal dapat dijelaskan bahwa perempuan keluarga miskin yang memiliki pendidikan lebih tinggi, mereka lebih memiliki keyakinan diri untuk mampu berhasil memperoleh pinjaman modal, melaksanakan proses produksi dalam usahanya, yakin mampu dapat berhasil dalam memasarkan produknya, dan yakin mampu dapat menjalin kerjasama dengan orang lain.

\section{3) Pendidikan Non Formal $\left(X_{3}\right)$}

Variabel pendidikan non formal dalam studi ini tidak berpengaruh signifikan terhadap self efficacy perempuan keluarga miskin dalam melaksanakan usaha ekonomi produktif dengan nilai koefisien sebesar 0,100 dan nilai thitung sebesar 0,898 lebih kecil dari nilai ttabel pada taraf signifikansi $=0,10$, yaitu sebesar 1,290. Hal ini berarti banyak sedikitnya jenis pendidikan non formal yang diikuti oleh perempuan rumah tangga miskin tidak mempengaruhi tingkat self efficacy-nya dalam melaksanakan usaha ekonomi produktif di Surakarta. Data di lapangan menunjukkan bahwa mayoritas perempuan keluarga miskin yang melaksanakan usaha ekonomi produktif di Surakarta belum pernah mengikuti pelatihan atau penyuluhan berkaitan dengan bidang usaha yang mereka tekuni. Pendidikan non formal yang sudah pernah diikuti oleh sebagian perempuan keluarga miskin mayoritas pelatihan menjahit, memasak, dan mengoperasikan komputer. Di Surakarta sebenarnya ada bidang khusus untuk pemberdayaan perempuan, tetapi yang diberdayakan lebih pada perempuan yang potensial untuk dapat dikembangkan. Dalam proses produksi mereka sebenarnya sudah trampil karena usaha yang mereka lakukan sudah dijalankan secara turun temurun, namun belum ditunjang adanya teknologi yang bisa meningkatkan omset produksinya. Ketika ada tawaran untuk pinjaman modal yang lebih besar untuk mengantikan peralatan yang ada mereka tidak mau, contoh kasus pada pembuat tempe ketika ditawari untuk kredit alat mesin pemecah kedelai yang seharga 2 juta-an mereka tidak mau, dengan berbagai alasan takut tidak bisa mengangsur, takut tidak laku kalau kebanyakan produksinya, tidak bisa menggunakan mesinnya, lebih repot dan sebagainya.

\section{4) Lama Usaha $\left(X_{4}\right)$}

Hasil analisis regresi variabel lama usaha tidak berpengaruh signifikan terhadap self efficacy perempuan keluarga miskin dalam melaksanakan usaha ekonomi produktif dengan nilai koefisien sebesar $-0,072$ dan nilai t-hitung sebesar -1,192 lebih kecil dari nilai ttabel pada taraf signifikansi $=0,10$, yaitu sebesar 1,290. Variabel lama usaha merupakan salah satu faktor karakteristik sosiodemografi yang tidak berpengaruh signifikan terhadap self efficacy, namun memiliki kecenderungan arah yang negatif. Data di lapangan menunjukkan bahwa lama usaha perempuan keluarga miskin dalam melaksanakan usaha mayoritas di atas 10 tahun, waktu yang tidak sebentar. Apabila dikaitkan dengan pengalaman dalam melaksanakan usaha, tentunya sudah tidak diragukan lagi bahwa mereka pasti sudah memiliki pengalaman bagaimana mengajukan pinjaman modal usaha agar berhasil, bagaimana melaksanakan proses produksi yang efisien, sudah mengetahui cara-cara memperoleh konsumen yang potensial, dan sudah memiliki banyak mitra dalam melaksanakan usahanya tersebut. Namun kenyataan di lapangan, lama usaha yang identik dengan pengalaman usaha tidak berpengaruh signifikan terhadap self efficacy. Kondisi ini dapat dimaknai bahwa lama tidaknya usaha yang dilaksanakan oleh perempuan rumah tangga miskin dalam usaha ekonomi produktif tidak mempengaruhi self efficacy-nya dalam melaksanakan usaha ekonomi produktif. Artinya, perempuan keluarga miskin yang sudah lama dalam melaksanakan usaha dengan yang belum lama melaksanakan usaha tidak berbeda self efficacy-nya atau keyakinan dirinya untuk mampu berhasil dalam memperoleh modal usaha, melakukan proses produksi, memasarkan produknya, dan menjalin kemitraan dengan pihak lain.

\section{5) Jumlah Tanggungan Keluarga $\left(\mathrm{X}_{5}\right)$}

Jumlah tanggungan keluarga merupakan semua anggota keluarga yang berada atau bertempat tinggal dalam satu rumah, yaitu terdiri dari kepala keluarga (suami), istri, anak-anak, orang 
tua atau orang lain tanpa ikatan kekeluargaan yang menjadi tanggungan untuk dibiayai. Keseluruhan individu tersebut beraktivitas dalam satu rumah dengan kurun waktu yang panjang, dan ada keterkaitan antara tiap-tiap individu terhadap kondisi rumah tersebut. Hasil studi menunjukkan bahwa variabel jumlah tanggungan keluarga berpengaruh signifikan terhadap self efficacy perempuan keluarga miskin dalam melaksanakan usaha ekonomi produktif, dengan nilai koefisien regresi sebesar 0,485 , dan nilai t-hitung sebesar 1,617 lebih besar dari t-tabel yaitu 1,290 pada taraf signifikansi $=0,10$, atau dapat dilihat pada nilai sig 0,083 lebih kecil dari alpha 0,10. Artinya, perempuan rumah tangga miskin yang memiliki jumlah tanggungan keluarga sedikit self efficacy-nya atau keyakinan diri untuk mampu berhasil dalam melaksanakan usaha semakin rendah, begitu juga sebaliknya, semakin banyak jumlah tanggungan keluarganya semakin tinggi keyakinannya untuk mampu berhasil dalam melaksanakan usaha. Kondisi ini dapat dijelaskan bahwa ternyata, banyaknya jumlah tanggungan keluarga pada masing-masing keluarga, bagi mereka merupakan beban keluarga sekaligus sebagai aset keluarga.

Kondisi usaha perempuan keluarga miskin akan semakin terpuruk apabila mereka tidak dibantu oleh anggota keluarga yang lain, karena untuk mengambil tenaga kerja dari orang lain sulit dilakukan menginggat biaya yang harus dikeluarkan untuk tenaga kerja relatif mahal. Dapat dibayangkan bahwa dalam hal permodalan untuk usaha yang mereka lakukan masih relatif kecil yaitu berkisar antara 100-200 ribu rupiah. Modal tersebut, kebanyakan mereka peroleh dari pinjaman (hutang) baik dari PKK, koperasi, tetangga, keluarga maupun teman. Melihat kondisi tersebut di atas sudah sewajarnya apabila jumlah tanggungan keluarga merupakan hal yang dapat mempengaruhi self efficacy perempuan rumah keluarga dalam melaksanakan usaha ekonomi produktif di Surakarta.

Untuk melihat goodness of fit model regresi linear berganda atau seberapa besar kemampuan variabel independen dalam menjelaskan varian variabel dependen ditunjukkan oleh nilai koefisien determinasi Adjusted $R^{2}$. Hasil analisis menunjukkan bahwa nilai koefisien determinasi Adjusted $R^{2}$, diperoleh nilai Adjusted $R^{2}$ sebesar 0,286. Hal ini menggambarkan bahwa kemampuan variabel karakteristik sosiodemografi dalam menjelaskan varians variabel self efficacy perempuan rumah tangga miskin dalam melaksanakan usaha ekonomi produktif sebesar 28,6 persen, sedangkan sisanya sebesar 62,4 persen belum mampu dijelaskan oleh variabel independen dalam model studi ini. Hal ini dapat dijelaskan bahwa variabel umur, pendidikan formal, pendidikan non formal, lama usaha, dan jumlah tanggungan keluarga secara bersama-sama mempengaruhi self efficacy perempuan rumah tangga miskin dalam melaksanakan usaha.

Pada Tabel 4 menunjukkan bahwa pengaruh variabel independen terhadap variabel dependen secara bersama-sama juga dapat digunakan uji F. Dari hasil analisis dapat diketahui bahwa nilai $\mathrm{F}$ hitung $=2,783$, dimana apabila nilai F-hitung lebih besar dari nilai $\mathrm{F}$-tabel pada tingkat signifikansi $=0,05$, yaitu sebesar 2,106, maka dapat diartikan bahwa memang benar terdapat pengaruh secara bersama-sama antara variabel umur, pendidikan formal, pendidikan non formal, lama usaha, dan jumlah tanggungan keluarga terhadap self efficacy perempuan rumah tangga miskin dalam melaksanakan usaha ekonomi produktif. Hal ini juga diperkuat dengan signifikansi yang memiliki nilai 0,001 lebih kecil dari taraf signifikansi $=0,05$.

\section{KESIMPULAN DAN SARAN}

\section{Kesimpulan}

Berdasarkan hasil analisis pengaruh karakteristik sosiodemografi perempuan rumah tangga miskin terhadap sefl efficacy dalam melaksanakan usaha ekonomi produktif, dapat diperoleh kesimpulan bahwa:

(1) Karakteristik sosiodemografi perempuan rumah tangga miskin di Surakarta, ratarata berumur 49 tahun, memiliki tingkat pendidikan formal mayoritas lulus SMP, sebagian besar belum pernah mengikuti pendidikan non formal, rata-rata waktu lama usahanya di atas 10 tahun, dan jumlah tanggungan keluarganya rata-rata 4 orang. 
(2) Hasil analisis regresi umur perempuan rumah tangga miskin berpengaruh signifikan dan arahnya negatif terhadap self efficacy melaksanakan usaha ekonomi produktif, artinya semakin tua umur perempuan rumah tangga miskin semakin rendah self efficacy-nya. Hal ini disebabkan karena semakin tua umur kondisi fisiknya semakin menurun, sehingga keyakinan dirinya dalam melaksanakan usaha yang meliputi permodalan, produksi, pemasaran, dan kemitraan juga menurun.

(3) Pendidikan formal perempuan rumah tangga miskin berpengaruh signifikan terhadap self efficacy dalam melaksanakan usaha ekonomi produktif. Hal ini dapat dimaknai bahwa tinggi rendahnya pendidikan formal perempuan rumah tangga miskin mempengaruhi tingkat self efficacy-nya dalam melaksanakan usaha ekonomi produktif, karena dengan bertambahnya ilmu, maka pola pikirnya akan lebih baik sehingga diharapkan memiliki keyakinan diri untuk mampu berhasil dalam melaksanakan usaha ekonomi produktif.

(4) Pendidikan non formal perempuan rumah tangga miskin tidak berpengaruh signifikan terhadap self efficacy dalam melaksanakan usaha ekonomi produktif. Perempuan rumah tangga miskin yang banyak mengikuti pelatihan maupun penyuluhan, tingkat self efficacy-nya sama dengan perempuan yang belum pernah mengikuti pendidikan non formal berkaitan dengan usahanya.

(5) Lama usaha perempuan rumah tangga miskin tidak berpengaruh signifikan terhadap terhadap self efficacy dalam melaksanakan usaha ekonomi produktif. Hal ini dapat dijelaskan bahwa perempuan rumah tangga miskin yang sudah lama berusaha dan yang belum lama berusaha tidak mempengaruhi self efficacy-nya dalam melaksanakan usaha ekonomi produktif.

(6) Jumlah tanggungan keluarga perempuan rumah tangga miskin berpengaruh signifikan terhadap self efficacy dalam melaksanakan usaha ekonomi produktif, artinya semakin banyak jumlah tanggungan keluarganya semakin tinggi self efficacy-nya dalam melaksanakan usaha ekonomi produktif. Kondisi ini dapat dijelaskan bahwa keyakinan diri perempuan rumah tangga miskin dalam memperoleh permodalan, memproduksi, memasarkan produk, dan menjalin kemitraan, akan meningkat sejalan dengan meningkatnya jumlah tanggungan keluarga, karena keluarga dianggap sebagai aset usaha yang mereka jalankan.

\section{Saran}

Berdasarkan hasil penelitian yang telah dilakukan, ada beberapa saran yang perlu disampaikan kepada pihak-pihak yang berkepentingan dengan pemberdayaan perempuan rumah tangga miskin dalam usaha ekonomi produktif, bahwa untuk meningkatkan self efficacy perempuan rumah tangga miskin dalam usaha ekonomi produktif, sebaiknya dalam memberdayakan perempuan rumah tangga miskin dalam melaksanakan usaha ekonomi produktif, para petugas perlu mempertimbangkan umur (dewasa awal), bentuk pelatihannya tidak hanya sekedar memberikan pelatihan atau penyuluhan dalam proses produksi saja, tetapi lebih ke arah peningkatan self efficacy-nya, seperti mengajak mereka studi banding pada sesama perempuan rumah tangga miskin yang sukses usahanya. Mereka dipandu untuk langsung mempraktekkan pengetahuan atau ketrampilan yang sudah diberikan, agar supaya memiliki pengalaman langsung, dan tidak henti-hentinya membujuk mereka agar memiliki sikap yang berorentasi pada masa depan yang lebih baik.

\section{DAFTAR PUSTAKA}

Bandura, A., 1997, Self Efficacy: The Exercise of Control, New York: WH. Freeman and Company.

BPS. 2012. Jawa Tengah Dalam Angka 2012. Semarang: Badan Pusat Statistik Propinsi Jawa Tengah.

2011. Surakarta Dalam Angka. Surakarta: BPS Kota Surakarta.

Dahama, O.P., dan Bhatnagar, 1980, Education and Communication for Development, Oxford \& IBH Publishing Co. New Delhi. 
Ghozali, I.. 2011. Aplikasi Analisis Multivariate Dengan Program IBM-SPSS 19. Semarang: Universitas Diponegoro.

Gibson, J.L., Ivancevich, J.M.,dan Donnelly, J.H.. 1997. Organizations: Behavior, Structure, Processes. Chicago: IRWIN.

Rini, J.F.. 2005. Wanita Bekerja. www.epsikologi.com.

Santoso, S., 2002. Buku Latihan SPSS Statistik Multivariat. Jakarta: Penerbit PT. Alex Media Komputindo. Gramedia.

Stajkovic S., dan Luthans, M., 1998. Dimensi Dari Self Efficacy Available.
http//www.emory.edu./Education/effstajko vic.ppt;Oktober 9, 2011.

Tjitropranoto, P., 1994. Agricultural Research and Extention Linkage. Paper Presented at the international Course on Agricultural Extention. Ciawi. Bogor.

Utami, Hamidah N., 2006. Pemberdayaan, Kemajuan, dan Keberlanjutan Usaha Pengrajin: Kasus Kabupaten Sidoarjo dan Kabupaten Magetan Provinsi Jawa Timur. Disertasi. Bogor: IPB Sekolah Pascasarjana. 